\title{
The Influence of the School Literacy Movement, Reading Interest, and Reading Materials on Reading Comprehension Skill of Class XI Students of MAN Bengkulu City Academic Year 2020/2021
}

\author{
Eryanti; Sudarwan Danim; Didi Yulistio; Dian Eka Chandra \\ Universitas Bengkulu, Indonesia \\ http://dx.doi.org/10.18415/ijmmu.v8i9.3002
}

\begin{abstract}
This study aims to determine the influence of the School Literacy Movement, reading interest, and reading materials on reading comprehension skills. This study uses descriptive method and quantitative approach, and also multiple regression technique. The population in this study amounted to 278 students. The sample is 74 students taken by random sampling. Data collection technique used instruments in the form of questionnaires and tests. The data analysis technique used multiple regression. The results showed that there were (1) significant influence between School Literacy Movement on reading comprehension skill, (2) significant influence of reading interest on reading comprehension skill, (3) significant influence of reading material on reading comprehension skill. Thus, it can be concluded that there is a significant influence of the School Literacy Movement, reading interest, and reading materials simultaneously on reading comprehension skill.
\end{abstract}

Keywords: Literacy; Interests; Reading Materials; Reading Comprehension

\section{Introduction}

Improving the quality of education and quality resources produced in the learning process is the basis for the government to make a breakthrough by holding a school literacy movement. The school literacy movement is an effort made so that school residents are literate for life with public involvement. The School Literacy Movement (Gerakan Literasi Sekolah) carried out are, 1) Familiarization of fun reading activities in the school ecosystem. 2) Development of reading interest to improve literacy skills. 3) Implementation of literacy-based learning. Reading activities at this stage support the implementation of the 2013 Curriculum which requires students to read non-lesson books which can be books on general knowledge, hobbies, special interests, or multimodal texts, and can also be linked to certain subjects (School Literacy Movement Task Force, 2019:50).

This school literacy movement strengthens the growth of reading habits according to Permendikbud Number 23 of 2015, i.e., the cultivation of character through 15 minutes of non-lesson reading activities before the lesson begins. This is in line with Santrock (2011: 424) who stated that getting students to read every day will help to improve reading skills. The habit of reading if done continuously will build a character of reading interest. Through regular reading activities, it is expected that reading 
habits (culture) will grow and students will finally have the skill to understand the contents of the reading. Harjasujana (1991: 4) states that reading ability is determined by 65\% intensity, 25\% IQ, and 10\% environment.

Interest in reading is a feeling of pleasure toward something with high effort. Fostering interest in reading can be done through intensifying reading both fiction and non-fiction reading materials. In line with this, Nurhadi (2010: 14) states that someone who has a high interest and attention to certain reading materials will certainly get a better understanding of the topic compared to people who are less interested in the topic. Becker, McElvany and Kortenbruck (2010) found that reading interest has ongoing positive influences on reading achievement. Thus, children who like to read will be able to develop their creative thinking patterns (Leonhardt, 2001).

Reading comprehension needs special attention. Nurgiyantoro (2010: 369) reveals that reading comprehension should receive special attention because in reading comprehension activities, readers are required to really understand the information and get the right meaning in the reading. In line with this, Subadiyono (2014: 5) states that the reading comprehension process focuses on three aspects, i.e., the text being read, the background knowledge possessed by the reader, and the context (such as region and environment) that are relevant in interpreting the text.

Piaget (in Irwantoro, 2016: 64) states that in the formal operational phase (14 years old to adulthood) they have been able to reason using abstract things and use logic. For the character of students at this stage, the higher the cognitive level of a person, which is the process of finding experience, the more organized and abstract the way of thinking is. At this point, students need to be trained to hone their abstraction skills through reading comprehension. Furthermore, previous studies found that Barrett's taxonomy can be used to determine the ability to understand reading by: (1) literal understanding, (2) reorganization, (3) inferential understanding, (4) evaluation, and (5) appreciation (Hafni, 1981: 33-37; Supriyono, 2008: 1; Tollefson as cited in Subadiyono, 2014: 8; Wibowo et al., 2016: 2396; Ahuja as cited in Junining, 2017:12; Tantri, 2016: 6433).

Abidin (2017: 1) states that literacy is the ability to use language and images in rich and diverse forms to read, write, listen, speak, see, present, and think critically about ideas. This is in line with Freire (2005) who states that literacy has been seen as a social construction and is never neutral. This means that the text written by the author has been shaped according to their position. The author's position includes aspects of beliefs, values, attitudes, social positions, and experiences. Because the position of the writer is different from that of the readers, it is very important for students to develop critical literacy skills. Thus, the School Literacy Movement (GLS) is an overall effort to make schools a learning organization whose citizens are literate for life through public involvement (Faizah et al., 2016; Sutrianto, 2016: 9).

Sinambela in Sudarsana (2010: 4.27) states that reading interest is "a positive attitude and a sense of interest in a person toward reading activities and being interested in reading books". According to Rahim (2008: 28), reading interest is a strong desire accompanied by an individual's efforts to read. A strong interest in reading is manifested in the individual's willingness to get a reading material and then read it on their own motivation. Dalman (2017: 141) states that reading interest is an activity carried out with great diligence in order to build a pattern of communication with oneself to find the meaning of writing and find information to develop intellectually which is done with awareness and feelings of pleasure that arise from within them.

Tarigan (2015: 107) states that basically reading materials are divided into scientific readings (nonfiction) and literary readings (fiction). The word scientific is defined as being scientific or fulfilling the requirements (rules) of science. Scientific reading contains knowledge or information written in straightforward, practical, and efficient reading. Tarigan (2011: 63) further states that non-fiction is an essay whose contents are not fantasy but reality. Literary reading is an essay whose contents are imaginary-it is not an actual reality.

The Influence of the School Literacy Movement, Reading Interest, and Reading Materials on Reading Comprehension Skill of Clas s XI Students of MAN Bengkulu City Academic Year 2020/2021 


\section{Research Method}

The method used in this study is descriptive method and quantitative approach with multiple regression technique. The population of this study was 278 students of year XI MAN 2 Bengkulu City and a sample of 74 students was taken by random sampling. This is done because the sample comes from members of a homogeneous population. The data collection technique used a questionnaire for the variables of school literacy movement, reading interest, and reading materials, and a test for the variable of reading comprehension skill. The data analysis technique used is descriptive and inferential analysis with multiple regression. Prior to the analysis through multiple regression, a prerequisite test was carried out with a normality test and a linearity test.

\section{Research Results and Discussion}

The results of the linearity test of the relationship between GLS and reading comprehension skill found an F (Deviation from Linearity) value of 1.233 and a p value (Sig.) of 0.263. The relationship between reading interest and reading comprehension skill has an $\mathrm{F}$ (Deviation from Linearity) value of 0.903 with a $\mathrm{p}$ value (Sig.) of 0.616 . The relationship between reading materials and the ability to read and understand found the value of $F$ (Deviation from Linearity) at 1.648 with a p-value (Sig.) of 0.067. Because the p value $>0.05$, it is said that the relationship between the variables is linear.

\section{The Influence of the School Literacy Movement (GLS) Program on Reading Comprehension Skill}

The hypothesis testing in this study is using the t-test. T-test is used to measure the influence of one variable on other variables. In this study, the authors tested the hypothesis of the influence of $\mathrm{X}_{1}$ (School Literacy Movement) on Y (Reading comprehension skill). The first hypothesis states that there is a significant influence of the School Literacy Movement (GLS) on the students' reading comprehension skill at Madrasah Aliyah Negeri 2 (MAN 2) Bengkulu City. Hypothesis testing was obtained by SPSS 26 program calculation.

The first hypothesis analysis resulted in statistical calculations. The $t_{\text {count }}$ value was greater than the $t_{\text {table }}$ value with $\mathrm{N}=74$ at an error level of $5 \%(2.063>2.000)$ and the $\mathrm{p}$ value $=0.043$ less than 0.05 . The magnitude of the influence is indicated by the correlation value of 0.248 . This means that there is the contribution of the school literacy movement variable $\left(\mathrm{X}_{1}\right)$ in influencing reading comprehension skill (Y) is $6.15 \%$.

The results of this study prove that there is a significant influence between the school literacy movement (GLS) on reading comprehension skills. The increasing school literacy movement resulted in an increase in students' reading comprehension skills. This is in line with the behavioristic learning theory proposed by Watson (in Irwantoro, 2016: 60) changing behavior can be done through training to familiarize them with the stimuli received. Motivation in reading is needed in order to encourage students to love reading (Wheatley, Gerde, \& Cabell, 2016: 83-92).

\section{Reading Interest on Reading comprehension skill}

The analysis in the second hypothesis resulted in the contribution of reading interest variables on reading comprehension skill as indicated by statistical calculations. The $t_{\text {count }}$ value is greater than the $t_{\text {table }}$ value with $\mathrm{N}=74$ at an error level of $5 \%(2.238>2.000)$ and the $\mathrm{p}$ value $=0.028$, or less than 0.05 . The magnitude of the influence is indicated by the correlation value of 0.319 . This means that the contribution of the school literacy movement variable $\left(\mathrm{X}_{1}\right)$ in influencing reading comprehension skill $(\mathrm{Y})$ is $10.2 \%$. The results of this study prove that there is a significant influence between reading interest on reading comprehension skill. Increased interest in reading resulted in an increase in students' reading comprehension skills. 


\section{The Influence of Reading Materials on Reading Comprehension Skill}

In the third hypothesis analysis, the contribution of the reading material variable to the reading comprehension skill is indicated by the $t_{\text {count }}$ value greater than the $t_{\text {table }}$ value with $\mathrm{N}=74$, at an error level of $5 \%(2.533>2.000)$ and the $\mathrm{p}$ value $=0.014$, or less than 0.05 . The magnitude of the influence is indicated by the correlation value of 0.300 . It means that the contribution of reading material variable $\left(\mathrm{X}_{3}\right)$ in influencing reading comprehension skill $(\mathrm{Y})$ is $9 \%$. The increased reading material resulted in an increase in students' reading comprehension skill. This is in line with Rahim's (2008:85) study in which reading material that has an attraction for students will motivate students to read the text seriously, and will further support students' reading comprehension.

\section{The Influence of the School Literacy Movement Program (GLS), Reading Interest, and Reading Materials on Reading Comprehension skill}

Hypothesis testing in this study was using Multiple Regression test. Multiple Regression Test was used to measure the influence of three independent variables simultaneously with one dependent variable. In this study, the authors tested the hypothesis of the influence of $\mathrm{X}_{1}$ (School Literacy Movement), $\mathrm{X}_{2}$ (Reading Interest), and $\mathrm{X}_{3}$ (Reading Materials) on $\mathrm{Y}$ (Reading comprehension skill). The first hypothesis states that there is a significant influence of the School Literacy Movement (GLS), reading interest, and reading materials on the reading comprehension skill of students in Madrasah Aliyah Negeri 2 (MAN) Bengkulu City. Hypothesis testing was obtained by the calculation from the SPSS 26 program.

The calculation results for testing the significance of multiple correlation coefficients are presented below.

Table 1 Results of Calculation of Correlation Values of School Literacy Movement (X1), Reading Interest (X2), and Reading Materials (X3) on Reading comprehension skill (Y)

\begin{tabular}{crrrr}
\hline Model & R & R Square & Adjusted R Square & Std. Error of the Estimate \\
\hline 1 & $.799^{\text {a }}$ & .639 & .624 & 6.23062 \\
\hline
\end{tabular}

a. Predictors: (Constant), School Literacy Movement (GLS), Reading Interest, Reading Materials

\section{b. Dependent Variable: Reading Comprehension Skill}

Table 4.1 describes the relationship between the School Literacy Movement (GLS), reading interest, and reading materials on reading comprehension skill. The value of the correlation $(\mathrm{R})$ between the School Literacy Movement $\left(\mathrm{X}_{1}\right)$, Reading Interest $\left(\mathrm{X}_{2}\right)$, Reading Materials $\left(\mathrm{X}_{3}\right)$ and Reading Comprehension (Y) is 0.799 . Because the value is between $0.6-0.8$, the relationship is said to be in a strong (strong) category. The value of the coefficient of determination ( $R$ Square $=R^{2}$ ) between the School Literacy Movement $\left(\mathrm{X}_{1}\right)$, reading interest $\left(\mathrm{X}_{2}\right)$, reading materials $\left(\mathrm{X}_{3}\right)$ on reading comprehension skill $(\mathrm{Y})$ is 0.639 . This means that the contribution of school literacy movement variable $\left(\mathrm{X}_{1}\right)$, reading interest $\left(\mathrm{X}_{2}\right)$, and reading materials $\left(\mathrm{X}_{3}\right)$ to reading comprehension skill $(\mathrm{Y})$ is $63.9 \%$, while $36.1 \%$ is influenced by other variables not examined in this study. This shows an increase in school literacy movement, interest in reading, and reading materials. 
Table 2 ANOVA Calculation Result of Multiple Correlation Coefficient $X_{1}, X_{2}, X_{3}$ on $Y$

\begin{tabular}{l|l|r|r|r|r|r}
\hline \multicolumn{2}{|c|}{ Model } & \multicolumn{1}{c|}{$\begin{array}{c}\text { Sum of } \\
\text { Squares }\end{array}$} & \multicolumn{1}{c|}{ Df } & \multicolumn{1}{c|}{$\begin{array}{c}\text { Mean } \\
\text { Square }\end{array}$} & F & \multicolumn{1}{c}{ Sig. } \\
\hline \multirow{2}{*}{1} & Regression & 4810.045 & 3 & 1603.348 & 41.302 & $.000^{\mathrm{b}}$ \\
\cline { 2 - 7 } & Residual & 2717.440 & 70 & 38.821 & & \\
\cline { 2 - 7 } & Total & 7527.485 & 73 & & & \\
\hline
\end{tabular}

a. Dependent Variable: Tests

b. Predictors: (Constant), Interest in reading, GLS, reading materials

From the ANOVA test or $\mathbf{F}$ test, the calculated $\mathrm{F}$ value is 41.302 and the F-table is 2.74 with a pvalue of 0.000 . Because the F-count $>$ F-table or $p$ value $<0.05$, the regression model can be used to predict reading comprehension skill. This means that, simultaneously, GLS $\left(\mathrm{X}_{1}\right)$, Reading Interest $\left(\mathrm{X}_{2}\right)$, and Reading Materials $\left(\mathrm{X}_{3}\right)$ influence reading comprehension skill (Y). Based on the calculation results, it shows that the hypothesis $\mathrm{H}_{\mathrm{o}}$ is rejected and $\mathrm{H}_{1}$ is accepted.

Table 3. Multiple Regression Coefficient

\begin{tabular}{|c|c|c|c|c|c|c|}
\hline \multicolumn{7}{|c|}{ Coefficients } \\
\hline & & \multicolumn{2}{|c|}{$\begin{array}{l}\text { Unstandardized } \\
\text { Coefficients }\end{array}$} & $\begin{array}{l}\text { Standardized } \\
\text { Coefficients }\end{array}$ & & \\
\hline Model & & $\mathrm{B}$ & Std Error & Beta & $\mathrm{T}$ & Sig \\
\hline \multirow[t]{4}{*}{1} & (Constant) & 3.586 & 7.358 & & .487 & .628 \\
\hline & GLS & 261 & 126 & .248 & 2.063 & .043 \\
\hline & Reading Interest & 207 & .082 & .319 & 2.533 & .014 \\
\hline & Reading Materials & 209 & .093 & .300 & 2.238 & .0 .28 \\
\hline
\end{tabular}

a. Dependent Variable Testing

Based on Table 4.3, it is obtained the Multiple Linear Regression equation between School Literacy Movement (GLS), Reading Interest, and reading materials on reading comprehension skill, i.e., $\widehat{Y}$ $=3.586+0.261 \mathrm{X}_{1}+0.207 \mathrm{X}_{2}+0.209 \mathrm{X}_{3}$.

Reading comprehension is an interactive process involving the reader, the reading, and the context (Silliman \& Wilkinson, 2007). Reading comprehension involves the skill to derive meaning from written texts. In its measurement, students' reading comprehension skill can be seen after they understand the reading, either by making a summary orally or in writing or answering several questions that measure students' understanding of reading (Sulikhah, Utomo, \& Santoso, 2020).

\section{Conclusion}

The results of this study conclude that the school literacy movement (GLS) has an influence on reading ability with a contribution of $6.2 \%$. Furthermore, there is the influence of reading interest on reading comprehension skill. The amount of contribution is $10.2 \%$. There is also an influence of reading materials on reading comprehension skill. The amount of the contribution is $9 \%$. There is a simultaneous influence of school literacy movements, reading interest, and reading materials on reading comprehension skill. The amount of the contribution is $63.9 \%$. 


\section{References}

Ahuja, P. \& Ahuja, G. C. (2010). Membaca Secara Efektif dan Efisien. Bandung: PT Kiblat Buku Utama

Alex\&Achmad.(2010).Bahasa Indonesia untuk Perguruan Tinggi. Jakarta: Kencana Prenada Media Group.

Amin, M., Suci Larasati, S., \& Fathurrochman, I. (2018). Implementasi Manajemen Kesiswaan Dalam Meningkatkan Prestasi Non Akademik Di SMP Kreatif 'Aisyiyah Rejang Lebong. Journal Literasiologi, 1(1), 103-121. https://doi.org/10.1017/CBO9781107415324.004

Anderson, L dan D. Krathwol. 2001. Kerangka landasan untuk pembelajaran pengajaran, pengajaran dan asesmen Revisi Taksonomi Pendidikan Bloom. Yogyakarta: Pustaka Pelajar.

Anderson, N. (2003). "Reading” dalam Praktikal Language Teaching reading. David Nunan (ed). New York: McGrow Hall.

Antoro, Billy. (2017). Gerakan Literasi Sekolah. Jakarta: Kementerian Pendidikan dan Kebudayaan.

Ardasheva, Y., Wang, Z., Roo, A. K., Adesope, O. O., \& Morrison, J. A. (2018). Representation visuals' impacts on science interest and reading comprehension of adolescent English learners. Journal of Educational Research, 111(5), 631-643. https://doi.org/10.1080/00220671.2017.1389681

Bano, J., Jabeen, Z., \& Qutoshi, S. B. (2018). Perceptions of Teachers about the Role of Parents in Developing Reading Habits of Children to Improve their Academic Performance in Schools. Journal of Education and Educational Development, 5(1), 42. https://doi.org/10.22555/joeed.v5i1.1445

Barton, David dan Mary Hamilton.(2000). "Literacy Practices", dalam David Barton, Mary Hamilton, dan Roz Ivanič (ed.). Situated Literacies: Reading and Writing in Context. London dan New York: Routledge Baynham, Mike. (1995). Literacy Practices: Investigating Literacy in Social Contexts. London: Longman. Budiman, D. A., Fathurrochman, I., Putra, M. R. E., \& Bahri, S. (2019). The Cultural Value and Character Education of Full Day School Implementation in Indonesia. (2), 3313-3318. https://doi.org/10.35940/ijeat.B3545.129219

Burn, P.C. Roe, Betly D. \& Ross, E.P. (1996). Teaching Reading in Today's Elementary schools. Boston: Hougthon Mifflin Company.

Burnes, Don. Glenda Page. (1985). Insights and Strategies for Reading. Sydney: Harcourt Brace Jovanovich Group.

Burnett, E. H. \& Berg, P. C. (1988). Reading instruction in the schools: improving students' critical thinking skills.The Clearing House:A Journal of Educational Strategies, Issues and Ideas, 61(5), 208-210.

Damaianti, V.S. (2003). "Strategi Polisional melalui Dramatisasi dalam Meningkatkan Motivasi Membaca”. Dalam Harras, K.A., Kurniawan, K, dan anshori, d.S. (penyunting). Mendamba Indonesia yang Literat. Bandung: Jurusan Pendidikan Bahasa dan Indonesia FPBS UPI.

Davies, Alan. (2010). Language Testing Simposium. London: Oxford.

Depertemen Pendidikan Nasional. 2004a. Kterampilan Dasar untuk Hidup. Literasi Membaca, Matetatika dan Sains. Laporan Program for International Student Assessment. Jakarta: Pusat Penilaian Pendidikan, Badan Penelitian dan Pengembangan, Departemen Pendidikan Nasional

Dubin, Fraida, dkk. 1986. Teaching Second Language Reading for Academic Purposes. Menlo Park: Addison-Wesley Publishing Company.

Duke, N. K. 2005. Comprehension of what for what: Comprehension as a nonunitary construct. In S. G. Paris \& S. A. Stah (Eds.), Children's reading comprehension and assessment (pp. 93-104). Routledge.

Duncan, L. G., Mcgeown, S. P., Griffiths, Y. M., Stothard, S. E., \& Dobai, A. 2016. Adolescent reading skill and engagement with digital and traditional literacies as predictors of reading comprehension. British Journal of Psychology, 107(2), 209-238. https://doi.org/10.1111/bjop.12134

Ecalle, J., Magnan, A., \& Gibert, F. 2006. Class size effects on literacy skills and literacy interest in first grade: A large-scale investigation. Journal of school psychology, 44(3), 191-209. https://doi.org/10.1016/j.jsp.2006.03.002

Elliot, Jessica A., 2015. "Middle school leisure reading selection: Influences during selection and implications for school library programs". Graduate Research Papers. 64. https://scholarworks.uni.edu/grp/ (tanggal akses 16 Februari 2021)

Fahrurrozia. (2017). Relationship between Students' Reading Interest and Vocabulary Mastery with Reading Comprehension ability. ISBN 978-94-6252-419-4. https://doi.org/10.2991/icset-17.2017.59

Faizah, Dewi Utama, et al. (2016). Panduan Gerakan Literasi Sekolah di Sekolah Dasar. Jakarta: Direktorat Jendral Pendidikan Dasar dan Menengah Kemeterian Pendidikan dan Kebudayaan.

The Influence of the School Literacy Movement, Reading Interest, and Reading Materials on Reading Comprehension Skill of Clas s XI Students of MAN Bengkulu City Academic Year 2020/2021 
Fathurrochman, I. (2017). Implementasi Manajemen Kurikulum Dalam Upaya Meningkatkan Mutu Santri Pondok Pesantren Hidayatullah/Panti Asuhan Anak Soleh Curup. Tadbir: Jurnal Studi Manajemen Pendidikan, 1(1), 85-104.

Fathurrochman, I. (2017). Pengembangan kompetensi pegawai aparatur sipil negara (ASN) Sekolah Tinggi Agama Islam Negeri (STAIN) Curup. Manajer Pendidikan, 11(21), 120-129.

Fathurrochman, I. (2018). Integrasi Media Sosial Pada Pembelajaran Mata Kuliah Filsafat Pendidikan Islam. Journal of Education and Instruction, 1(1), $29-41$. https://doi.org/10.1017/CBO9781107415324.004

Fathurrochman, I. (2020). Pendidikan Sebagai Media Integrasi Agama Dan Sains Dalam Era Revolusi Industri 4.0. Jurnal Literasiologi, 3(1).

Fathurrochman, I., \& Apriani, E. (2017). Pendidikan Karakter Prespektif Pendidikan Islam Dalam Upaya Deradikalisasi Paham Radikal. POTENSIA: Jurnal Kependidikan Islam, 3(1), 122-142.

Fathurrochman, I., Budiman, D. A., Alamsyahril, \& Kristiawan, M. (2019). Revitalization Management Of Islamic Boarding School Preventing The Radicalism. Restaurant Business, (10), 495-505. Retrieved from https://journals.eduindex.org/index.php/rb/article/view/9462

Fox, E., \& Alexander, P. A. 2004. Reading, interest, and the model of domain learning: A developmental model of interest, knowledge, and strategy use in text comprehension. In meeting of the American Educational Research Association, San Diego, CA. http://okp.uinjkt.ac.id/wpcontent/uploads/2020/10/artikel-reading-interest-and-reading-comprehension-ratna-sari-dewi-TalentJournal-Q2.pdf

Galus, Ben S. 2011. Budaya Baca Orang Indonesia Masih Rendah. Dinas Pendidikan, Pemuda, \& Olahraga Daerah Istimewa Yogyakarta. Diakses dari http://www.pendidikandiy.go.id/dinas_v4/?vv_artikel\&id=8. pada tanggal 8 November 2019, jam 11.00 WIB

Haroun, Z. 2018. Le dispositif pédagogique, cadre d'analyse du processus d'enseignement et d'évaluation de la compréhension de l'écrit. XLinguae, 11(1XL), 138-149. https://doi.org/10.18355/XL.2018.11.01XL.12

Haroun, Z. 2018. Le dispositif pédagogique, cadre d'analyse du processus d'enseignement et d'évaluation de la compréhension de l'écrit. XLinguae, 11(1XL), 138-149. https://doi.org/10.18355/XL.2018.11.01XL.12

Harras, A. Kholid 2011. Family Literacy: Kiat Membutuhkan Potensi dan Kemampuan literasi Anak-anak. Harris, Albert J. \& Edward R.Sipay. 1980. How to increase Reading Ability. New York: Longman.

Hasanah, Atsna Nur. 2016. Analisis Korelasi Ganda. Surabaya: Universitas Surabaya.

Heath, Shirley Brice dan Brian V. Street. 2008. On Ethnography: Approaches to Language and Literacy Research. New York: Teachers College Press bekerja sama dengan National Conference on Research in Language and Literacy (NCRLL).

Heather Thomas. 2013. An evaluation of the literacy program at Garibal Grade School. Doctor of Education. George Fox University.

Hernawan. 2009. Bahasa dan Sastra Indonesia di Tengah Arus Global. Bandung: PBSI UPI

Heryati, Y., dkk. 2010. Model Inovatif Pembelajaran Bahasa Indonesia. Jakarta: Multi Kreasi Satudelapan.

Hidi, S. 2001. Interest, reading, and learning: Theoretical and practical considerations. Educational Psychology Review,13 (3), 191-209. Retrieved from https://www.msu.edu

Hough, Lindall. 2003. Language, Context, and Meaning. Sidney: Heinemann.

Howard, Vivian.2011. The Important of Pleasure Reading in the Live of young Teens:Self-Identification, Self-Construction and Self-Awareness. Journal Librarianship and Information Science. 43 (1): 46-55 https://journals.sagepub.com/doi/abs/10.1177/0961000610390992

Hritcu, O., \& Schipor, M. D. 2014. A study on children's interest towards reading- A questionnaire-based survey. Education and Development, Research and Practice (EDRP), 1(1), 1-7.

Iskandarwassit dan Dadang Sunendar. 2009. Strategi Pembelajaran Bahasa. Bandung: Remaja Rosdakarya Offset.

J., \& Nurmi, J.-E. 2017. Profiles of teaching practices and first and third graders' reading skills in Finland and Estonia. Teaching and Teacher Education, 64, 150-161. 
Janjic;Watrich, Vera. 2009. "The cambridge handbook of literacy” by Olson, D.R. \& Torrance, R. (Eds). Books Review. Alberta Journal of Educational Research, Winter, 55,4. Diunduh pada 15 Maret 2013. http://www.proquest/umi/pqd. web

Johansone, I. (2017). Survey Operations Procedures in PIRLS 2016. Methods and Procedures in PIRLS 2016, 1-26. https://doi.org/978-1-88993-44-8

Karademir, E. \& Ulucinar, U. 2017. Examining the relationship between middle school students' critical reading skills, science literacy skills and attitudes: A structural equation modeling. Journal of Education in Science, Environment and Health (JESEH),3(1),2017ISSN:2149-214X. https://files.eric.ed.gov/fulltext/EJ1125758.pdf (pada tanggal 20 September 2020, pukul 12.30)

Karamalak, O., \& Pesina, S. 2017. Linguistic sign and reading as text creating activity. XLinguae, 10(1), 2-11. https://doi.org/10.18355/XL.2017.10.01.01

Kartanegara, Mulyadhi. 2005. Seni Mengukir Kata: Kiat-Kiat Menulis Efektif Kreatif. Bandung: Mizan Learning Centre.

Kasiyun, Suharmono. 2015. Upaya Meningkatkan Minat Baca sebagai Sarana untuk Mencerdaskan Bangsa. Jurnal Bahasa Indonesia, Sastra, dan Pengajarannya Volume 1, Nomor 1, Maret 2015 ISSN: 22477-5150

Kem, R. 2000. Literacy and Language Teaching. Oxford: Oxford University Press.

Kikas, E., Pakarinen, E., Soodla, P., Peets, K., \& Lerkkanen, M. K. 2018. Associations Between Reading Skills, Interest in Reading, and Teaching Practices in First Grade. Scandinavian Journal of Educational Research, 62(6), 832-849. https://doi.org/10.1080/00313831.2017.1307272

Kikas, E., Silinskas, G., \&Soodla, P. 2015. The effects of children's reading skills and interest on teacher perceptions of children's skills and individualized support. International Journal of Behavioral Development, 39(5), 402-412. https://doi.org/10.1177/0165025415573641

King, C.M., and Stanley, L.M. 2004. Teaching Reading Skills in a foreign Language. Oxford:Oxford University Press.

Kuşdemir, Y., \& Bulut, P. 2018. The Relationship between Elementary School Students' Reading Comprehension and Reading Motivation. Journal of Education and Training Studies, 6(12), 97. https://doi.org/10.11114/jets.v6i12.3595

Kusen, K., Hidayat, R., Fathurrochman, I., \& Hamengkubuwono, H. (2019). STRATEGI KEPALA SEKOLAH DAN IMPLEMENTASINYA DALAM PENINGKATAN KOMPETENSI GURU. Idaarah: Jurnal Manajemen Pendidikan, 3(2), 175-193.

M.C. McKenna \& R.D. Robinson. 1997. Teaching through text: A content literacy approach to content area reading. White Plains, NY: Longman.

Majid Asgari, Saeed Ketabi, Zahra Amirian. 2019. Interest-based Language Teaching: Enhancing Students' Interest and Achievement in L2 Reading. EJ1201792.pdf

Maloch, B., \& Bomer, R. 2013. Research and Policy: Informational Texts and the Common Core Standards: What Are We Talking about, Anyway?. Language Arts, 90(3), 205-213.

Mandarani. 2017. Kajian Minat Membaca Siswa terhadap Karya Sastra. Pedagogia: Jurnal Pendidikan. . http://dx.doi.org/10.21070/pedagogia.v6i1.608

Mar'at, Samsunuwiyati. 2015. Psikolinguistik. Bandung: Refika Aditama.

Mardotella, M., Fathurrochman, I., Sugiatno, S., Hamengkubuwono, H., \& Amin, M. (2019). Manajemen Dosen Penasehat Akademik dalam Meningkatkan Motivasi Kuliah Mahasiswa. ALIGNMENT: Journal of Administration and Educational Management, 2(2), 139-147.

Maynard, Katrina L., dan Paige C. Pullen. 2010. Literacy Research and Instruction. Diakses dari http://www.proquest.umi.com,

Meniado, J. C. 2016. Metacognitive Reading Strategies, Motivation, and Reading Comprehension Performance of Saudi EFL Students. English Language Teaching, 9(3), 117. https://doi.org/10.5539/elt.v9n3p117

Metsäpelto, R. L., Silinskas, G., Kiuru, N., Poikkeus, A. M., Pakarinen, E., Vasalampi, K., ... \& Nurmi, J. E. 2017. Externalizing behavior problems and interest in reading as predictors of later reading skills and educational aspirations. Contemporary Educational Psychology, 49, 324-336. https://doi.org/10.1016/j. cedpsych.2017.03.009 
Miller, John W. dan Micahel M. McKenna. 2016. World Literacy: How Countries Rank and Why It Matters. New York: Routledge.

Muijselaar, M. M. L., Swart, N. M., Steenbeek-Planting, E. G., Droop, M., Verhoeven, L., \& de Jong, P. F. (2017). Developmental Relations Between Reading Comprehension and Reading Strategies. Scientific Studies of Reading, 21(3), 194-209. https://doi.org/10.1080/10888438.2017.1278763

Muis, S. F. 2013. Kemampuan Membaca Pemahaman Literal dan Interpretatif melalui Pendekatan Konstruktivisme. Al-MUNZIR, 6(2).

Murshidi, Al Gadah. 2014. UAE University Male Students' Interests Impact on Reading and Writing Performance and Improvement. English Language Teaching, 7(9), 57-63. https://doi.org/10.5539/elt.v7n9p57

Musfah, Jejen. 2012. Peningkatan Kompetensi Guru. Jakarta: Kencana Frenada.

Nasiruddin, U. A., \& Hum, S. M. 2018. Strategies to support foreign language learning in large classes: A systematic literature review. XLinguae, 11(1), 3-15. https://doi.org/10.18355/XL.2018.11.01.01

Nida, Eugene A. 1957. Learning of Foreign Language, An Arbor: Cushing Molloy.

Nurdiyanti, Eko \& Suryanto Edy. 2010. Pembelajaran Literasi Mata Pelajaran Bahasa Indonesia pada Siswa Kelas V Sekolah Dasar. Paedagogia, 13 (2), Agustus 2010, 115 - 128.

Nurgiyantoro, Burhan. 2010. Teori Pengkajian Fiksi. Yogyakarta: Gadjah Mada.

Nurhayati Pandawa Hairudin Mislinatul Sakdiyah. 2009. Pembelajaran Membaca. Jakarta: Departemen Pendidikan nasional.

Nuttal, C. 1985. Teaching Reading Skills in Foreign Language. London: Heinemann Educational Books

OECD. 2019. PISA 2018 Results Vol III: What School Life Means for Students' Lives. 2019 (Vol. III). Paris: OECD Publishing. https://doi.org/10.1787/acd78851-en

Paul, R. \& Elder, L. (2008). The miniature guide to critical thinking concepts and tools. Dillon Beach, CA: Foundation for Critical Thinking Press.

Pilgreen, Janice L. 2000. The SSR Handbook: How to Organize and Manage a Sustained

Pumfrey, Peter D. 1977. Measuring Reading abilities: Concepts, Sounces and Applications. London:

Hodder and Stroughton,

Purwanto, M. Ngalim.2007. Psikologi Pendidikan. Bandung: Remaja Rosdakarya.

Putra R.S. 2008. Menumbuhkan minat baca Sejak dini. Jakarta: PT Indeks.

Puwanto, Wachid Eko. 2007. "Menghidupi Tradisi Literasi: Problematika bagi Siswa, Guru, Sekolah, dan Negara". http://www.titikoma.com/esai. Diakses pada 14 Februari 2020.

Rahim, Farida. 2008. Pengajaran Membaca di Sekolah Dasar. Jakarta: Bumi Aksara.

Ralph C. Wilson. 2016. Students' Reading Interests Impact on Reading ComprehensionAbilitieshttps://fisherpub.sjfc.edu/cgi/viewcontent.cgi?article=1330\&context=education _ETD_masters

Ramlannariesblog, 2010. Manfaat membaca Buku diakses tanggal 10 Feb 2019.Htttp://ramlannarie.Wordpress.com/2010/06/09/ manfaat.membaca.buku/

Ribeiro, I., Cadime, I., Freitas, T., \& Viana, F. L. (2016). Beyond word recognition, fluency, and vocabulary: The influence of reasoning on reading comprehension. AustralianJournalofPsychology,68(2), 107-115. https://doi.org/10.1111/ajpy.12095

Ristianti, D. H. (2018). Konseling Islami Untuk Meningkatkan Efikasi Diri Pasien HIV/AIDS. Indonesian Journal of Educational Counseling, 2(1), 113-130. https://doi.org/10.30653/001.201821.29

Ristianti, D. H., Danim, S., Winarto, H., \& Dharmayana, I. W. (2019). The Development Of Group Counselling Assessment Instruments. International Journal of Scientific \& Technology Research, 8(10), 267-272. Retrieved from http://www.ijstr.org/paper-references.php?ref=IJSTR-1019-23814

Rohman, S. 2017. Membangun Budaya Membaca pada Anak Melalui Program Gerakan Literasi Sekolah. Jurnal Pendidikan dan Pembelajaran Dasar, 4(1): 151-174.tersedia di http://ejournal.radenintan.ac.id/index.php/ terampil/article/viewFile/2118/1602 (diunduh 11 Februari 2020).

Rozak, A., Fathurrochman, I., \& Ristianti, D. H. (2018). Analisis Pelaksanaan Bimbingan Belajar Dalam Mengatasi Kesulitan Belajar Siswa. Journal of Education and Instruction (JOEAI), 1(1), 10-20. https://doi.org/10.1017/CBO9781107415324.004

Rubin Dorothy. 1982. A Practical Approach to Teaching Reading. New York: CBS College Publishing.

The Influence of the School Literacy Movement, Reading Interest, and Reading Materials on Reading Comprehension Skill of Clas s XI Students of MAN Bengkulu City Academic Year 2020/2021 
Rumainah. Undergraduate Students' Reading Interest and Reading Comprehension Achievement in a State Islamic University. Journal of Islamic Educa tion - Volume 23, Number 1, June 201854 Available online at http://jurnal.radenfatah.a c.id/i ndex.php/ta dib

Snow, C. 2002. Reading for Understanding. Pittsburgh: Rand

Somadayo, Samsu. 2011. Strategi dan Teknik Pembelajaran Membaca. Yogyakarta: Graha Ilmu.

Subadiyono. 2014. Pembelajaran Membaca.Palembang: Noer Fikri Offset.

Sugiyono.2019. Metode Penelitian Pendidikan. Bandung: Alfabeta.

Suherli, dkk. 2017. Bahasa Indonesia Kelas XI SMA/ MA/ SMK/ MAK. (edisi revisi 2017). Jakarta: Pusat Kurikulum dan Perbukuan, Balitbang, Kemendikbud.

Tang, X., Kikas, E., Pakarinen, E., Lerkkanen, M.-K., Muotka, J., \& Nurmi, J.-E. 2017. Profiles of teaching practices and first and third graders' reading skills in Finland and Estonia. Teaching and Teacher Education, 64, 150-161.

Tollefson, James W. 1996. “A System for Improving Teachers' Questioning” dalam Teacher Development Making the Right Moves, Thomas Kral (ed), Washington D.C.: United States Information Agency,

Trim, Bambang. 2016. Melejitkan Daya Literasi Indonesia: sebuah kajian pendahuluan, Jakarta: institut penulis indonesia,

Trosky, Odarka S. 1973. "Teachers' Questioning Behavior in the Development of Reading Comprehension," dalam The Quest for Competency in Teaching Reading, Howard A. Klein (ed), Delawara: Newark

Tryanasari, D., Aprilia, S., \& Cahya, W. A. 2017. Pembelajaran Literasi di SDN Rejosari 1 Kecamatan Kawedanan Kabupaten Magetan. Premiere Educandum: Jurnal Pendidikan Dasar dan Pembelajaran, 7(02), 173-179.

Umar, Touku. 2013. Perpustakaan sekolah dalam menanamkan budaya membaca. Jurnal: UIN Alauddin, Gowa

United States Department of Education. 2005. Helping your child become a reader. Washington: ED Pubs.

Vacca, R. 2020. From Efficient Decoders to Strategic Read. Educational Landership, 60 (3), 6-11.

Veliz, L., \& Veliz-Campos, M. (2019). An interrogation of the role of critical thinking in English language pedagogy in Chile. Teaching in Higher Education, 24(1), 47-62. https://doi.org/10.1080/13562517.2018.1456424

Wahab, Romalina. 2016. Psikologi Belajar. Jakarta: Raja Grafindo Persada.

Wainwright, Gordon. 2006. Speed Reading Better Recolling: Memanfaatkan Teknik Teruji untuk Membaca lebih Cepat dan Mengingat Secara Maksimal. Jakarta: Gramedia Pustaka Utama.

Wandasari, Y. 2017. Implementasi Gerakan Literasi Sekolah (GLS) sebagai Pembentuk Pendidikan Berkarakter. Jurnal Manajemen, Kepemimpinan, dan Supervisi Pendidikan, 1(1): 325-343. Tersedia di https:// media. neliti. com/media/publications/230884-implementasi-gerakan-literasi-sekolahglfecb51ed.pdf (diunduh 14 Februari 2020).

Wellington, J. \& Osborne, J. 2001. Language and literacy in science education. Buckingham Philadelphia: Open University Press.

Wheatley, B. C., Gerde, H. K., \& Cabell, S. Q. 2016. Integrating Early Writing into Science Instruction in Preschool. Reading Teacher, 70(1), 83-92. https://doi.org/10.1002/trtr.1470

Wildova, Radka. 2014. Initial Reading Literacy Development in Current Primary School Practice. Procedia - Social and Behavioral Sciences 159: 334-339. (http://www.sciencedirect.com/science)

Yunus Abidin, dkk . 2017. Pembelajaran literasi. Jakarta: Bumi aksara.

Zabihi, R. \& Pordel, M. (2011). An investigation of critical reading in reading textbooks: A qualitative analysis. International Education Studies, 4(3).

\section{Copyrights}

Copyright for this article is retained by the author(s), with first publication rights granted to the journal.

This is an open-access article distributed under the terms and conditions of the Creative Commons Attribution license (http://creativecommons.org/licenses/by/4.0/). 